RESEARCH ARTICLE

\title{
The Substantiation of Dose for Presowing Treatment of Cereal Seeds in Electromagnetic Field of Industrial Frequency
}

\section{Nikolai I. Shabanov*, Nikolai V. Ksenz, Vladimir S. Gazalov, Mariya V. Zholobova, Mihail G. Fedorishchenko}

Azov-Black Sea Engineering Institute branch of the Federal State Budgetary Educational Institution of Higher Education "Don State Agrarian University" Ulitsa Lenina, 21, Zernograd, Rostovskaya oblast', Russia, 347740

Study Area: Zernograd, Russia

Coordinates: $46^{\circ} 51^{\prime} \mathrm{N} ; 40^{\circ} 19^{\prime} \mathrm{E}$

Key words: Radiation dose, Magnetic induction, Moisture content of seeds

\section{Introduction:}

Electromagnetic treatment of seeds before sowing stimulates internal processes in the seed, strengthening the activity of hydrolytic and oxidation-reduction enzymes, that accelerates the supply of nutrients to the corcule and thus stimulates the growth processes. It is known, that the influence of electromagnetic field (EMF) increases the number of fertile tillers, ears, grains in the ear and, accordingly, the mass of the grain, as well as the average length of the plant and ear. All this leads to an increase in the yield of agricultural crops (Zholobova, 2013; Starodubtseva et al., 2012; Vasiliev \& Kononenko, 2008; Gazalov et al., 2010; Ragha et al., 2011).

The electromagnetic field of industrial frequency (EMF IF) is an environmentally friendly process of presowing seed treatment. It does not give lethal doses for seed material, it is technologically simple and safely for operating personnel, it is easily coordinated with current agricultural practices. The effect of EMF can be accurately dosed, thereby ensuring the uniformity of seed treatment before sowing. According to many studies, the plants, grown from treated seeds, do not have pathological changes and induced mutations (Starodubtseva et al., 2012; Vasiliev \& Kononenko, 2008; Gazalov et al., 2010; Borodin, 2008).

Previously proposed equipment for seeds treatment in EMF IF before sowing did not always provide the required radiation dose, because of the uneven supply of seeds to the treatment zone, and non-stationary nature of the magnetic field. This led to the lack of efficiency of this process (Zholobova, 2013; Zholobova et al., 2013; Vasiliev \&

\section{Abstract}

The dose of presowing treatment of spring barley seeds of the varieties Vakula, Vikont, Ratnik in the electromagnetic field of industrial frequency $50 \mathrm{~Hz}$ is substantiated in this article. Laboratory facility with circular pole pieces of rectangular cross-section was used in the process of experimental studies. As a result of variance analysis, the data on the germination energy of spring barley seeds of the studied varieties were obtained. The best values of germination energy was reveled by the seeds of the Vikont variety, under the following conditions of treatment - the moisture content of the seed material was $16 \%$, the time of treatment was $2 \mathrm{~s}$, the level of magnetic induction was $27 \mathrm{mT}$, the radiation dose was $54 \mathrm{mTs}$.

Kononenko, 2008; Ereshko, 2000; Borodin, 2008). Also, the developers of equipment do not provide fully substantiated recommendations on the required doses of seed irradiation in EMF IF before sowing. Therefore, the studies, aimed at defining the required dose of seeds irradiation in EMF IF before their sowing in different conditions are relevant.

\section{Methodology:}

The research was carried out on the seeds of the midripening spring barley of the prospective varieties Vakula, Vikont and Ratnik. They are the main fodder-grain crops, and their yield is almost always lower than in winter crops. At the first stage, laboratory equipment for electromagnetic treatment of seeds with different doses of radiation was tested. It consists of the magnetizing coil with a magnetic core and seed container, made of non-magnetic material; timing relay with automatic switch-off; electromagnetic starter; and servomotor automatic voltage regulator (Fig.-1).

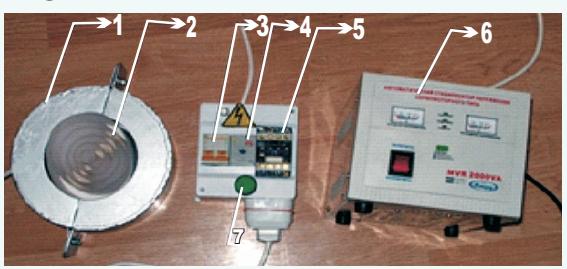

Figure-1: Facility and equipment for experimental research 1-magnetizing coil with magnetic core; 2-element of nonmagnetic material, dividing the space of the working chamber into sections; 3-automatic switch; 4-timing relay; 5electromagnetic starter; 6-automatic voltage regulator; 7-power button.

*Corresponding Author: info@ores.su 
Automatic switching control of the process of magnetic treatment of seeds (timing relay) ensured the setting of predetermined time for keeping the seeds in electromagnetic field. Magnetic induction was measured in the working chamber of the facility, in order to ensure the treatment of seeds in the homogeneous magnetic field. Based on the results of measurements, the curves, reflecting the changes of magnetic induction in the space of the working chamber of the facility were built (Zholobova, 2013; Zholobova et al., 2013; 2015). It defined, that the magnetic induction is uneven through the height of the chamber. It depended on the distance to its axis (Fig.-2).

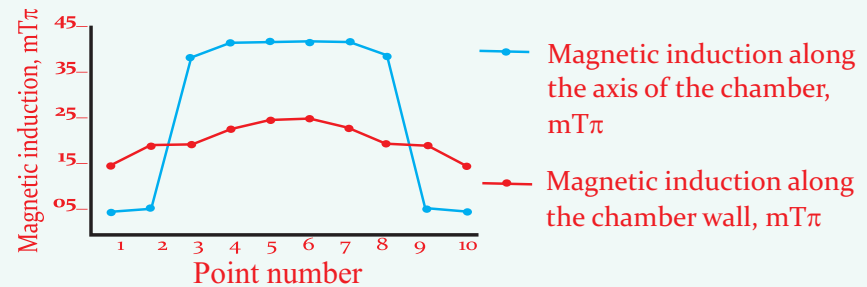

Figure-2: Distribution of magnetic induction through the height in the working chamber of the facility

According to the obtained data of magnetic induction in the space of working chamber, a container was made, which was necessary for the treatment of seed material. The shape of the container allowed to treat seeds in the magnetic field with magnetic induction $10 \pm 2.0 \mathrm{mT} \pi$, $27.0 \pm 2.0 \mathrm{mT} \pi, 35 \pm 2.0 \mathrm{mT} \pi$. The time of treatment was set in the range 0.5-5.0s. Consequently, the dose of radiation, obtained by spring barley seeds during the treatment in EMF IF depended on the level of magnetic induction and the time of seed treatment.

At the second stage, the research on the magnetic treatment of seeds with different moisture content was carried out. This parameter was controlled by the moisture indicator Wile-55. Seeds in the container, made of nonmagnetic material, with the previously established moisture content of 14,16 and $18 \%$ were alternately placed in the working chamber.

The experiments were carried out using the standard methods for determining the moisture content of seeds, evaluation the laboratory quality of seeds, special methods for studying electromagnetic devices and zones, for defining the required exposure dose in the process of treatment of spring barley seeds in EMF IF, in the working chamber of the facility (Zholobova,, 2013; Zholobova, et al., 2015; Starodubtsev et al., 2012).

\section{Results \& Discussion:}

As a result of these researches, the data on the germination energy of seeds of mid-ripening spring barley of the varieties Vakula, Vikont and Ratnik were obtained. We assessed the impact of one or more factors of the experimental research such as, the variety of spring barley, moisture content of seeds, time of treatment in EMF IF, magnetic induction in the space of the working chamber of the facility USE (p)-1o on the energy of germination (Zholobova et al., 2013).

The analysis of variance was carried out using the program Statistica 6.o. To estimate the influence of experimental factors - the variety of spring barley, moisture content of seeds $\mathrm{W}(\%)$, time of treatment in EMF IF T (s), and magnetic induction in the space of working chamber of the facility B $(\mathrm{mT} \pi)$ - on the germination energy of seeds of mid-ripening spring barley of the varieties Vakula, Vikont and Ratnik, we fix one of the factors.

First of all we fixed the value of magnetic induction in the space of the working chamber.

Table-1: Results of Analysis of Variance

\begin{tabular}{lllllll}
\hline \multirow{2}{*}{ Effect } & $\begin{array}{l}\text { Df } \\
\text { Effect }\end{array}$ & $\begin{array}{l}\text { Ms } \\
\text { Effect }\end{array}$ & $\begin{array}{l}\text { df } \\
\text { Error }\end{array}$ & $\begin{array}{l}\text { Ms } \\
\text { Error }\end{array}$ & $\mathrm{r}$ & p-value \\
\hline 1 & 2 & 33.531 & 54 & 3.741 & 8.964 & 0.0004 \\
2 & 2 & 60.383 & 54 & 3.741 & 16.142 & 0.0000 \\
3 & 2 & 34.823 & 54 & 3.741 & 9.310 & 0.0003 \\
12 & 4 & 3.364 & 54 & 3.741 & 0.899 & 0.4709 \\
13 & 4 & 3.920 & 54 & 3.741 & 1.048 & 0.3912 \\
23 & 4 & 2.105 & 54 & 3.741 & 0.563 & 0.6907 \\
123 & 8 & 1.114 & 54 & 3.741 & 0.2978 & 0.9636 \\
\hline
\end{tabular}

According to the results (Table-1), in case of fixing the value of magnetic induction in the space of working chamber B $(\mathrm{mT} \pi)$, all the three factors (the variety of spring barley, moisture content of seeds W (\%), time of treatment in EMF IF T (s)) revealed a great impact on the change in germination energy of seeds.

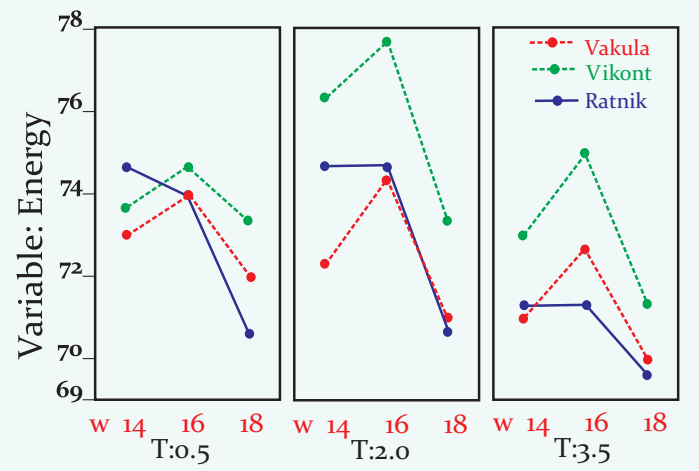

Figure-3: The graphs of comparison of mean values of germination energy $(\mathrm{W}, \mathrm{T})$

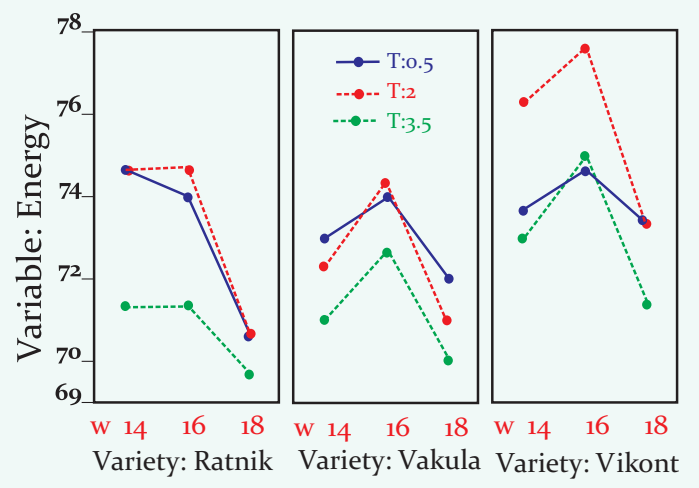

Figure-4: The graphs of comparison of mean values of germination energy (W, variety) 
As per the graphs of average values (Fig.-3,4), the best germination energy was obtained after the treatment of the seeds of Tthe variety-Vikont. The conditions of treatment were the following: $\mathrm{W}=16 \%, \mathrm{~T}=\mathbf{2} \mathrm{s}$. It is obvious, that when fixing the value of magnetic induction in the space of working chamber, the moisture content of seeds and the time of treatment in EMF IF exert a significant impact on the germination energy. The seeds of the variety-Vikont gave the best results of germination energy at the same parameters of treatment as the seeds of the variety-Vakula. The seeds of the variety-Ratnik in case of treatment during 2 $\mathrm{s}$ are similar to Vakula in value of germination energy, except for exposure of $3.5 \mathrm{~s}$. However, the energy of seed germination of the variety-Ratnik deteriorates with the increase in moisture content.

Next, we fix the time of treatment in $\operatorname{EMF~IFT~(s).~}$

Table-2: Results of Analysis of Variance

\begin{tabular}{lllllll}
\hline Effect & $\begin{array}{l}\text { Df } \\
\text { Effect }\end{array}$ & $\begin{array}{l}\text { Ms } \\
\text { Effect }\end{array}$ & $\begin{array}{l}\text { df } \\
\text { Error }\end{array}$ & $\begin{array}{l}\text { Ms } \\
\text { Error }\end{array}$ & $\mathrm{r}$ & p-value \\
\hline 1 & 2 & 33.531 & 54 & 4.555 & 7.360 & 0.0015 \\
2 & 2 & 60.383 & 54 & 4.555 & 13.255 & 0.0000 \\
3 & 2 & 15.197 & 54 & 4.555 & 3.336 & 0.0430 \\
12 & 4 & 3.364 & 54 & 4.555 & 0.738 & 0.5699 \\
13 & 4 & 0.290 & 54 & 4.555 & 0.064 & 0.9923 \\
23 & 4 & 1.809 & 54 & 4.555 & 0.397 & 0.8099 \\
123 & 8 & 2.484 & 54 & 4.555 & 0.545 & 0.8170 \\
\hline
\end{tabular}

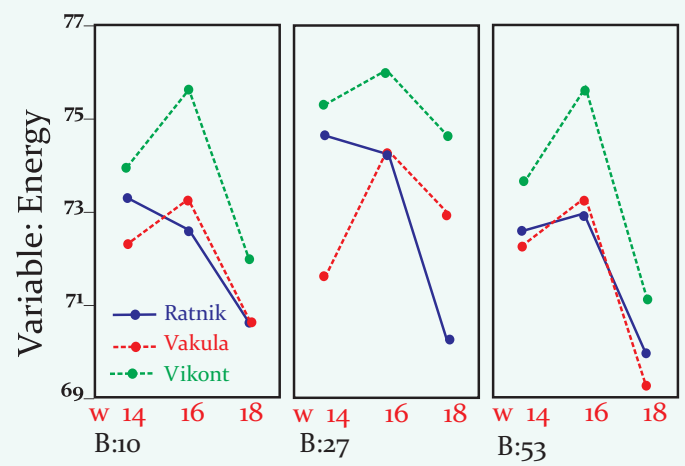

Figure-5: The graphs of comparison of mean values of germination energy $(\mathrm{W}, \mathrm{B})$

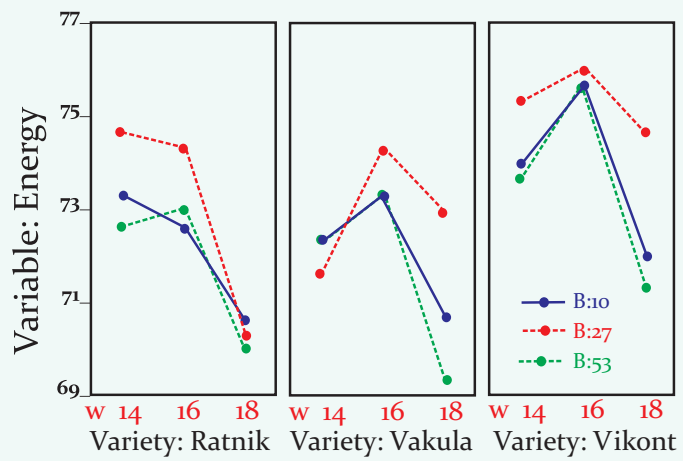

Figure-6: The graphs of comparison of mean values of germination energy ( $\mathrm{W}$, variety)
According to the analysis of initial data (Table-2), when fixing the time of treatment in EMF IF T (s), all the three factors exert a great impact on the change in germination energy: the variety of spring barley, the moisture content of seeds W (\%), the magnetic induction in the working chamber B $(\mathrm{mT} \pi)$.

According to the graphs of average values (Fig.-5, 6), the best energy of germination was obtained after the treatment of the seeds of the variety-Vikont. The conditions of treatment were the following: $\mathrm{W}=16 \%, \mathrm{~B}=27 \mathrm{mT} \pi$. It is obvious, that in case of fixed time of treatment in EMF IF, the seeds of the variety-Vikont, with moisture content $16 \%$, gave the values of germination energy close to $76 \%$, for all three values of magnetic induction. This indicated a signif icant influence of the moisture content in pre-sowing material, in case of treatment in EMF IF. The seeds of the variety Vakula gave better results of germination energy with the same parameters of treatment as the seeds of the variety-Vikont. The seeds of the variety-Ratnik were inferior in the value of germination energy to the varieties Vikont and Vakula.

Next, we fix the moisture content of seeds W (\%).

Table-3: Results of Analysis of Variance

\begin{tabular}{lllllll}
\hline \multirow{2}{*}{ Effect } & $\begin{array}{l}\text { Df } \\
\text { Effect }\end{array}$ & $\begin{array}{l}\text { Ms } \\
\text { Effect }\end{array}$ & $\begin{array}{l}\text { df } \\
\text { Error }\end{array}$ & $\begin{array}{l}\text { Ms } \\
\text { Error }\end{array}$ & & p-value \\
\hline 1 & 2 & 33.531 & 54 & 5.765 & 5.816 & 0.0051 \\
2 & 2 & 34.827 & 54 & 5.765 & 6.041 & 0.0042 \\
3 & 2 & 15.197 & 54 & 5.765 & 2.636 & 0.0808 \\
12 & 4 & 3.920 & 54 & 5.765 & 0.680 & 0.6090 \\
13 & 4 & 0.290 & 54 & 5.765 & 0.050 & 0.9951 \\
23 & 4 & 0.420 & 54 & 5.765 & 0.073 & 0.9900 \\
123 & 8 & 1.123 & 54 & 5.765 & 0.195 & 0.9905 \\
\hline
\end{tabular}

According to the Table-3, when fixed the moisture content of seeds W (\%), only two factors revealed a significant impact on the change in germination energy - the variety of spring barley, and the time of treatment in EMF IFT (s).

According to the graphs of average values (Fig.-7 \& 8), the best energy of germination was obtained after the treatment of the seeds of the variety-Vikont. The conditions of treatment were the following: $\mathrm{T}=2 \mathrm{~s}, \mathrm{~B}=27 \mathrm{mT} \pi$, hence the dose of treatment of spring barley seeds $\mathrm{D}=54 \mathrm{mT} \pi$. It is

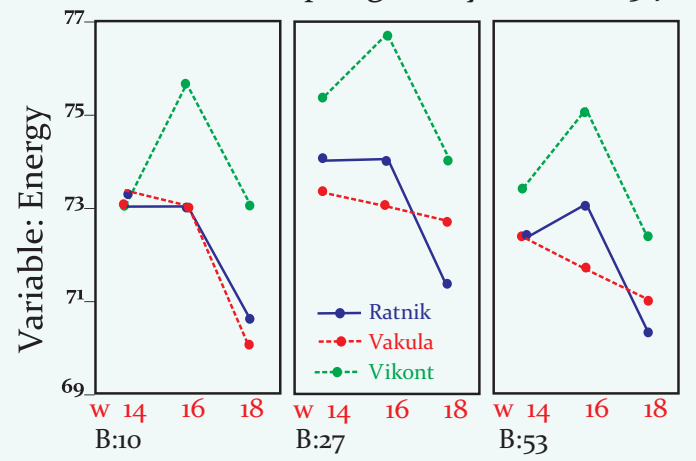

Figure-7: The graphs of comparison of mean values of germination energy ( $T, B)$ 


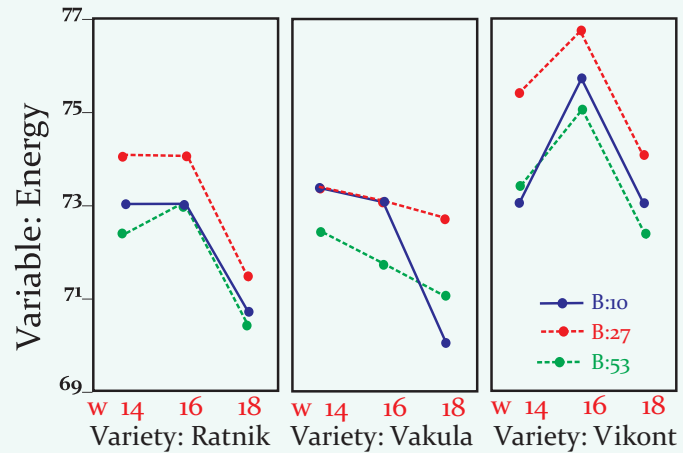

Figure-8: The graphs of comparison of mean values of germination energy ( $T$, variety)

obvious, that when fixing the moisture content of seeds, the variety of seeds, and the time of their treatment in EMF IF gave a great impact on the germination energy. Gendreau et al. (2008) demonstrated that at the tip of the radical of swelling barley seeds, an increase in humidity is accompanied by a decrease in the ABA content after 5 hours from the beginning of swelling and cell division begins 4-6 hours before the appearance of coleorhizae. The appearance of the radical occurs simultaneously with the activation of a number of genes that regulate cell division. Similarly, Bradford (1990) found that the germination rate of the lettuce seeds linearly depends on the increase in the turgor of the embryo cells.

The main indicators of economic evaluation towards the application of electromagnetic field of industrial frequency for pre-sowing treatment of spring barley seeds are the following: reduction in energy costs for pre-sowing treatment of production unit; reduction in the prime costs of the process of pre-sowing treatment of seeds; the increase in germination energy of seeds; the increase in the yield of agricultural crops; and the annual effect, received by the enterprise, in the form of net present value (NPV). However,, Kasakova et al. (2018) concluded that the presowing treatment of spring barley seeds in an alternating electromagnetic field of industrial frequency shortens the seed swelling period, but simultaneously leads to the achievement of a higher humidity during this time, which may be associated with an increase in the suction power of the seeds. In another study, Aguilar et al. (2009) reported that the effects produced by the alternating magnetic field applied pre-sowing depend on genotype and combination of irradiation parameters: magnetic flux density and irradiation time. In another word, it has been found that the effects of alternating magnetic field treatments, in maize seeds, depending on the seed genotype. Besides, Positive effects are dependent on the irradiation parameters (intensity and exposure time) used in the pre-sowing seed treatment.

Technical and economic evaluation of the application of EMF IF for pre-sowing treatment of seeds was carried out on the basis of data on material costs, labour costs for the performance of works, capacity of the installation, and energy of seed germination. When determining commercial eff iciency, the indicator Cash Flow is used.

The data of the technical and economic analysis conf irm the expediency of practical use of the proposed technology of presowing treatment of spring barley seeds in the electromagnetic field of industrial frequency.

Table-4: Results of calculation of net present value

\begin{tabular}{lllllll}
\hline Years & \multicolumn{5}{c}{ Indicators } \\
& $\begin{array}{l}\text { Inflow, } \\
\text { rubles }\end{array}$ & $\begin{array}{l}\text { Outflow, } \\
\text { rubles }\end{array}$ & $\begin{array}{l}\text { Cash Flow, } \\
\text { py6 }\end{array}$ & $\begin{array}{l}(1+E p) \wedge \\
(-t)\end{array}$ & $\begin{array}{l}\text { Cash } \\
\text { Flow* }\end{array}$ & NPV \\
\hline o & & 16500 & 16500 & 1 & 16500 & 16500 \\
1 & 222815 & & 0.9109 & 202972 & 186472 & \\
2 & 222815 & & 222815 & 0.8298 & 184895 & 371366 \\
3 & 222815 & 222815 & 0.7559 & 168428 & 539795 \\
4 & 222815 & 222815 & 0.6886 & 153428 & 693223 \\
5 & 222815 & 222815 & 0.6273 & 139764 & 832986 \\
6 & 222815 & 22815 & 0.5714 & 127316 & 960303 \\
7 & 222815 & 22815 & 0.5205 & 115978 & 1076281 \\
8 & 222815 & & 222815 & 0.4742 & 105649 & 1181929 \\
\hline
\end{tabular}

The data of the technical and economic analysis confirm the expediency of practical use of the proposed technology of presowing treatment of spring barley seeds in the electromagnetic field of industrial frequency.

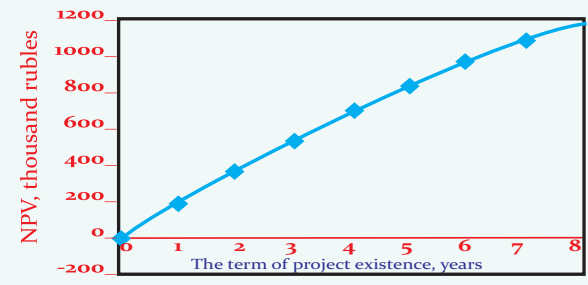

Figure-9: Graphical determination of the project payback period

\section{Conclusion:}

As a result of performed variance analysis, the data on the germination energy of spring barley seeds of the varieties; Vakula, Vikont, Ratnik were obtained. They showed that in the process of treatment of spring barley seeds in an alternating electromagnetic field of industrial frequency 50 $\mathrm{Hz}$, the best values of germination energy had the seeds of the variety-Vikont. The conditions of treatment were the following: $\mathrm{W}=16 \%, \mathrm{~T}=2 \mathrm{~s}, \mathrm{~B}=27 \mathrm{mT} \pi$, consequently, $\mathrm{D}=54 \mathrm{mT} \pi$.

Thus, the obtained data on the germination energy of the seeds of mid-ripening spring barley of the varieties Vakula, Vikont, and Ratnik, allowed evaluating the influence of experimental research factors on germination energy. The dose of radiation, obtained by seeds of spring barley in the process of treatment in EMF IF, can be regulated by the level of magnetic induction, and the time of seeds treatment. On the basis of the foregoing, it can be concluded that the proposed method is promising and that it can be used in the presowing treatment of seeds in EMF IF.

\section{References:}

Aguilar, C.H., Dominguez-Pacheco, A., Carballo, A.C., Cruz-Orea, A., Ivanov, R., Bonilla, J.L.L., \& Montañez, J.P.V. (2009). 
Alternating magnetic field irradiation effects on three genotype maize seed field performance Acta Agrophys., 14(1):7-17.Borodin I.F., (20o8), Nanoelectrotechnology in seed breeding book of reports Application of nanotechnologies and nanomaterials in Agro Industrial Complex, Federal State Scientific Institution. Pub. by: «Rosinformagrotech. Orel / Russia;pp.12-19.

Bradford, K.J. (1990): A water relation analysis of seed germination rate. Plant Physiol., 94(2):840-849.

Ereshko, A.S. (200o): Ways of increasing the yield of barley in the conditions of steppe zone of the North Caucasus. Dissertation for the scientific degree of Doctor of Agricultural Sciences. Kuban State Agrarian University. Krasnodar, Russia.

Gazalov, V.S. (2010): Evaluation of the sowing properties of spring barley seeds of the variety "Ratnik" after the treatment with optical radiation. In: V.S. Gazalov, K.N. Bukhantsov, N.E. Ponomareva edited- Resource-saving technologies and technical support for the innovative development of the agro-industrial complex: Collection of scientific works of the ${ }^{\text {th }}$ International research $\&$ practice conference (Zernograd, State Scientific Institution "North Caucasian Research Institute of Mechanization and Electrification of Agriculture" of the Russian Academy of Agricultural Sciences", May 27-28, 2010). - Zernograd, Pp. 180-183.

Kasakova, A.S., Yudaev, I.V., Fedorishchenko, M.G., Mayboroda, S.Yu., Ksenz, N.V., \& Voronin, S.M. (2018): New Approach to Study Stimulating Effect of the Pre-Sowing Barley Seeds Treatment in the Electromagnetic Field. OnLine J. Biol. Sci., 18(2):197-207.
Starodubtseva, G.P. , Rubtsova, E.I., Lapina, E.N., Bogolyubova, I.A. \& Menshikov, A.V. (2012): Development of the method for the presowing treatment of agricultural crops seeds, using the pulsed electric field (PEF) and economic substantiation of its application. Polythematic Network Elec. Sci. J. Kuban State Agrarian Uni., 75:1037-1051.

Vasiliev, A.N. \& Kononenko, A.F. (2008): Electrotechnology and management in the implementation of adaptive regimes of presowing grains processing with active vantilation. Pub. by: Terra Print, Rostov-na-Donu, Russia. $192 \mathrm{p}$.

Zholobova, M.V. (2013): Substantiation of parameters and regimes of treatment of spring barley seeds, using alternating electromagnetic field of industrial frequency for increasing their sowing qualities. Thesis for the academic degree of Cand. tech. sciences. Zernograd, Russia 2013. - 20 p.

Zholobova, M.V., Fedorishchenko, M.G., Shabanov, N.I. \& Gracheva, N.N. (2015): The Study of the Influence of an Alternating Electromagnetic Field of Commercial Frequency on Crop Seed Quality of Spring Barley. Polythematic Online Sci.J. Kuban State Agrarian Uni., 108(04):1-13.

Zholobova, M.V. , Fedorishchenko, M.G., Gracheva, N.N. (2013): Experiment Planning on preseeding Processing of Seeds by Variation Electromagnetic Field of Industrial Frequency. Polythematic Online Sci. J. Kuban State Agrarian Uni.,91(7):110

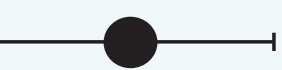

